Benedek Péter Tóta

\title{
Ruminating More and More Realism
}

\author{
Some Contextual Aspects of Thomas More's Utopia
}

in eius mensa

\section{CRITICAL CONTEXT}

The men first to write about Utopia, the contemporaries of Thomas More, "were concerned with the outcome rather than the nature of More's way of thinking."1 The same seems to be the case with the readers of later ages, too, when they search for the meaning of Utopia." The claim "to investigate the relation between the structure of Utopia and the meaning and intent of its author" almost entirely results in a concentration on the latter part of the assigned task. ${ }^{3}$ Such an imbalance leads to statements like "...the man of expedients proposes no expedients, the man of method no methods..."4 If it were true about More, it would really mean that "... in his view of men and their affairs there was a strong and ineradicable streak of pessimism." 5

'J. II. I Jexter, More's Utopia: the Biography' of an Idea (Princeton: Princeton University Press, 1952, rpt. 1976) p. 14.

2 George M. I.ogan, The Meaning of More's Ulopia (l'rinceton: P'rinceton University l'ress, 1983). Romuald Ian I akowski, Sir Thomas More and the Ant of Dialogue (PhD Dissertation, University of British Columbia, Fall 1993, Interactive Early Modern literary Studies, 1995, 1996).

${ }^{3}$ Cf. Hexter, p. 30.

+ Hexter, p. 59

5llexter, p. 72; cf. also R. Marius, Thomas More: a Biography (New York: Alfred A. Knopf, 1984), p. 269. 
Opposing it, an approach could be proposed based on life-like elements in More's fictitious frames and forms of art. These are elements like meals and food of any kind, concrete or metaphoric. If they symbolise some level of communion (or communication), they should be perhaps regarded as more than formulaic and perfunctory, ${ }^{6}$ they are not introduced hastily and without thought, interest or care, but they reflect the operation of thoughts offering some expedient method, i. e. rumination: consuming, chewing over, digesting and assimilating different components of reality. However, this ruminating method is not supposed to serve optimism either, but it can probably take the reader closer to More - and more realism.

For the sake of the immediate experience of this ruminative realism, More's texts will dominate this paper and confirm their contexts.

\section{HISTORICAL CONTEXT}

The idea of Utopia began to take shape in the summer of 1515. On 7 May More was assigned to serve as a member of a royal trade commission. The ambassadors, including More, left for Flanders on 12 May. The negotiations were suspended by 21 July, but More returned to England only on 25 October. During these three months he visited Antwerp, where he met l'eter Giles who was a classical scholar, an intimate of Erasmus, and a man of practical affairs. More also kept practical matters in mind. It is revealed by the letters he and his companions sent to the Council, to Henry VIII and to Wolsey on 9 July, 21 July and 1 October, respectively.

Lykethe it your good lordshippis to vnderstand, that as towching the state of our busynes her, for as moche as wee dowt not, but that our lettres, in whiche wee haue writton therof at large to the Kingis Grace, shall by his Highnes cume to your handis; wee therfor trouble not at this tyme your good lordshippis with the repeticion of the same, but the oonly cause of our present writing to your good lordshippis is to beseche the same to haue vs soo in your fauourable rememraunce, that wee may haue by the mean of your good lordshippis more money sent vnto vs. For as your lordshippis well remembre of lx days, for whiche wee receyued our money byfor the hand, and spent also a good parte therof byfor the hand, ther bee not remaynyng past iii or iiii days, fro the xiith day of May last at whiche day wee toke our

\footnotetext{
"Kenneth Jay Wilson, Incomplete Fictions: the Formation of the English Renaissunce Dialogue (Washington D. C.: The Catholic University of America l'ress, 1985) Pp. 144-145.
} 
journey. And as your good lordshippis well know, that wee had soo short warnyng of this journey, that our tyme was very lityll and skarse to prepayr our self and our company forward. And noo tyme had wee to make shifte and provision for any substans of our own hider with vs, by reason wherof wee haue been at some payn hider to. And if wee shold make farther shifte here, it wold bee our farther payn and losse also. Wherfor wee beseche your good lordshippis, that as your wisdoomes perceyve, that wee be lyke her to abyde, soo it wol lyke you to ordre that we may haue money sent vs. In whiche dooyng, your lordshippis shal bynd vs to owe you our poore seruice and our prayer. As knoweth our Lord, whos grace long preserue your good lordshippis. From Brugis the ixth day of July. [...] [B]y reason of certaine delayes ... wee be not yet cum to any final determynacion in oure matiers ... And this knowen we shall certifye youre Grace with all diligence, moost humbly beseking youre Grace to remembre vs with sum money towardis owre dyettes. [...] And thus blessed Trynyte preserue your Grace. At Brugys this first day of Octobre. ${ }^{7}$

As it becomes clear in these letters, the most practical matter which is repeated again and again without essential difference is the need for money with which they could provide for themselves. I version of this refrain found its way into Utopia. $\Lambda$ s the negotiations could not go on without the rhythm of proper diet, so the discussions in Utopia could not be kept on without the natural rhythm of eating. Fach book has been concluded with a meal.

... mi Raphael, inquam, quaeso te atque obsecro, describe nobis insulam: nec velis esse brevis, sed explices ... omnia quae nos putes velle cognoscere. $\mathrm{Pu}$ tabis autem velle quicquid adhuc nescimus.

Nihil, inquit, faciam libentius, nam haec in promptu habeo. Sed res otium poscit.

Eamus ergo, inquam, intro pransum: mox tempus nostro arbitratu sumemus. Fiat, inquit. Ita ingressi prandemus. Pransi in eundem reversi locum, in eodem sedili consedimus, ... ego ac Petrus $A$ egedius hortamur Raphaelem ut praestet quod erat pollicitus. Is ergo ubi nos vidit intentos atque avidos audiendi, quum paulisper tacitus et cogitabundus assedisset, hunc in modum exorsus

\footnotetext{
7 Elizabeth Frances Rogers, ed., The Correspondence of Sir Thomas More, (Princeton: Princeton University Press, 1947) pp. 20-21 and 24, italics mine.
} 


\section{est. PRIMI LIBRI FINIS. ${ }^{8}$}

'... my dear Raphael,' said I, 'I beg and beseech you, describe that island to us. Do not be brief, but explain ... in fact, everything that you think we would like to know. And you can assume we want to know everything we do not know yet.'

'There is nothing,' he said, 'I shall be more pleased to do, for these things are fresh in my mind. But it will take some time.'

'In that case,' said I, 'let us go in to lunch. Afterwards, we shall have all the time we want.'

'Agreed,' he said. So we went in and had lunch. Then [after lunch] we returned to the same place, sat down on the same bench ... Peter Giles and I urged Raphael to fulfil his promise. When he saw that we were attentive and eager to listen, he sat silent and thoughtful a moment, and began as follows. THF: ENI OF BOOK I"

IJaec ubi Raphael recensuit ... tamen, quniam defessum narrando sciebam, ... idcirco et illorum institutione et ipsius oratione laudata, manu apprehendens intro cenatum duco ... SE.CUNDI LIBRI IIINIS

$$
\text { (logan, pp. 246-248, italics mine) }
$$

When Raphael had finished his story ... I knew, however, that he was tired with talking ... So with praise for their way of life and his account of it, I took him by the hand and led him in to supper... END OF BOOK II (cf. Iogan, pp. 247-249, and CW4, pp. 245-247, italics mine)

The historical need for life seems to become a topos in making art alive through providing pulse for the work of art. Work and diet, writing and eating go together. Going a step farther: facing words provides food for thought, and this intellectual activity is metaphorically accompanied with physical nourishment.

\footnotetext{
8 Thomas More, Utopia, eds. George M. Logan, Robert M. Adams and Clarence II. Miller (Cambridge: Cambridgc University Press, 1994) p. 106., italics mine, hereafter referred to in the text as Logan "Cf. Logan, p. 107, and The Complete Works of St. Thomas More. Vol. 4. Utopia, ed. Jidward Surtz and J. II. Hexter (New IIaven: Yale Liniversity Press, 1965), p. 109, hereafter referred to as CW4. Italics and an insertion mine, based on the Jatin
} 


\section{EPISTOLARY CONTEXT}

Thomas More was anxious about the publication of Utopia. He expresses his care for it in a letter to Peter Giles in October 1516. This first letter is published in all of the early editions of Utopia. In the 1516 edition it is headed as 'Prefatio' (Iogan, pp. 30-39). Having been singled out among the prefatory addresses, this letter deserves special attention.

In the opening of the letter, More mentions the obligatory components of finding the material, refers to its arrangement and eloquent presentation. He repeats this classical triplet twice in the two introductory paragraphs, as he also states twice that he had only to recite what he had heard from his source. This simple task, however, nearly proved to be impossible due to the reasonable difficulties of writing among official and family ties.

Sed huic tamen tam nihilo negotii peragendo, cetera negotia mea minus fere quam nihil temporis reliquerunt. Dum causas forenses assidue alias ago, alias audio, alias arbiter finio, alias iudex dirimo, dum hic officii cause visitur, ille negotii, dum foris totum ferme diem aliis impertior, reliquum meis; relinquo mihi, hoc est literis, nihil.

(L.ogan, p. 32)

Yet even to carry through this trifling task, my other tasks left me practically no leisure at all. Most of my day is constantly given to the law: pleading some cases, hearing others, arbitrating others, and deciding still others, I pay a visit of courtesy to one man and go on business to another, so I devote almost the whole day in public to other people, and what is left - to my own; and I leave for myself, that is writing, nothing.

$$
\text { (ci. logan, p. 33, and (W/4, p. 39) }
$$

Due to the doublets, the introduction of this prefatory letter is quite tired, slow and nearly uninteresting, yet with the change of the pace in these lines - in spite of the catalogue of obligations and the cumulative repetition of lexical items - More quickly arrives at his most important activity, that is writing. The singularity of this art is emphasised by the apposition: mibi, boc est literis; for myself, that is writing. This grammatical closeness in such a stylistic peak-position can probably speak about the contextual unity of the artist and his art, revealing its gravity.

Proceeding in this way, after a solemn digression concerning family and household matters, More and the reader have to face the question: 
Quando ergo scribimus?

(Logan, p. 32)

When do we write then?

The answer seems to be conventional:

...mihi hoc solum temporis acquiro quod somno ciboque suffuror...

(Jogan, p. 32, italics mine)

...I get for myself only the time I steal from sleeping and eating...

(cf. Logan, p. 33, and CW4, p. 41, italics mine)

However conventional the answer is, it can convey the inherent meaning of the activity of writing in the case of Thomas More. Staying awake and restraining from food are ascetic attitudes. The prototype of the discipline of keeping vigil and fast is provided by Jesus Christ who fasted for forty days and forty nights in the wilderness (cf., Mt 4:2). These circumstances sharpen the awareness of one's task. On the one hand, Christ focuses on his role that is characterised by obedience when he quotes the Scripture: 'Man does not live on bread alone but on every word that comes from the mouth of God' (Mt 4:4). Vigilance illuminates the acknowledgement that the word is as important as food, and in special cases it is more important than natural nourishment. It is reflected in the fact that Christ is determined to rely on the words of the Scripture alone (Mt 4:7 and 10). On the other hand, More substitutes sleeping and eating with writing, that is during his vigilant dealing with words he finds food for thought nourishing him. As Christ started his public ministry after the wilderness scene of keeping vigil and fast, so did Thomas More become known to the public of European humanists after writing Utopiu in circumstances of vigil and fast. This public acknowledgement is echoed in other letters and poems published in critical editions: Erasmus to Johann Froben, Guillaume Bude to Thomas Lupset, Peter Giles to Jerome Busleyden, Jerome Busleyden to Thomas More, Gerard Geldenhouwer on Utopia, Cornelis de Schrijver to the Reader, Beatus Rhenanus to Willibald Pirckheimer, and Jean Desmare\% to Peter Giles (cf. Jogan, pp. 4-29, 250-265, and CW4, pp. 2-37, 252253). This correspondence is a kind of literary digestion of More's food for thought.

In his second letter to Peter Giles in August 1517, More returns to Utopia anew. This letter was published in the 1517 edition of Utopia immediately following the 
text of Book II. In this epilogue-like letter, More writes about an anonymous, perhaps fictitious critic to whom he is very much obliged (Logan, pp. 266-269).

Tantum etenim mihi iudicio hoc suo tam ingenuo quantum nescio an quisquam alius ab edito libello gratificatus est. Nam primum sive mei studio sive ipsius operis illectus, non laboris videtur fuisse pertaesus quominus totum perlegeret, neque id quidem perfunctorie ac praecipitanter quomodo sacerdotes horatias preces solent (videlicet hi qui solent), sed ita sensim ac sedulo ut interim singula sollerter expenderit.

(Logan, p. 266)

His very frank criticism has gratified me more than any other reaction since my little book appeared. First of all, attracted either by devotion to me or the work itself, he seems not to have wearied of the labour but read it through. And he did not read carelessly or quickly, as priests pray the divine office (those who pray it at all) but slowly and carefully in order to consider the different points thoughtfully.

(cf. logan, p. 267, and CW4, p. 249)

According to this slice of the letter, More is not interested in conventional laudation, but his interest can be found in a special attitude towards writing and reading. His interest is adjusted by a pair of antithetical alliteration (perfunctorie ac praecipitanter and sensim ac sedulo) refined by an additional one (singula sollerter) until focusing finally on the intellectual act (expenderit): to consider. This consideration is tuned further with the embedded simile of the priests praying the divine office if praying it at all, which means that the receiving of the word of the Scripture is at stake. Due to this concentrated construction, the proper way of reading is not only considering what is written, but even meditating upon the writing. This mental-spiritual discipline is as ascetic as keeping vigil and fast, since the person devoted to this act has to be on the watch and has to be satisfied only with what is written, that is, he has to feed upon nothing else but the word which is written as if it were real food - for thought.

To be more exact and explicit, I would propose to call this act rumination. Both the writer and the reader ruminate: consume, chew over, and digest the thought until it is assimilated. It is only interesting from this point of view, that the writer cannot really separate himself and his work (sive mei studio sive ipsins operis illectus; attracted either by devotion to me or the work itselff. This attitude of the epilogue-like letter of 1517 also repeats the characteristic apposition of the prologue-like letter of 
1516: myself, that is writing. The homogeneity of these words speaks about the integrity of this art.

\section{COMPOSTIIONAL CONTEXT}

In the opening sentence of his letter of October 1516 to Peter Giles, More apologises for the dclayed presentation of Utopia:

Pudet me propemodum, charissime Petre Aegidi, libellum hunc de Utopiana republica post anıum ferme ad te mittere, quem te non dubito intra sesquimensem expectasse.

(Logan, p. 30)

I am almost ashamed, my dear Peter Giles, to send you this little book about the state of Utopia after almost a year, which I am sure you expected within a month and a half.

$$
\text { (cf. Logan, p. } 31 \text { and CW4, p. 39) }
$$

More's certainty and Peter Giles' expectancy express that the little book of Utopia must have been composed by and large by the end of 1515 . However, something must have happened between the end of 1515 and October 1516. Soon after he returned to England, More was offered a place in the royal service along with a pension (CW4, p. xxxiii). ${ }^{11}$ This situation must have made him have second thoughts.

The introduction to the Yale Edition and an appendix (CW4, pp. xv-xxiii, and 572-576) work out which parts of Utopia were probably composed in Flanders (the introduction in Book I [CW4, pp. 46-58], and the discourse on Utopia in Book II [CIV4, pp. 110-236]), and which new parts were inserted into the Urutopia in England (the dialogue of counsel including the exordium in Book I [CW4, pp. 58-108], the peroration and the conclusion in Book II [CW4, pp. 236-46]). As has been made evident, some changes were introduced during the period in question. More accomplished a work and returned to it: de-created the extant composition and created an original work of art.

The above reconstructed outline suggests katabolism and anabolism. Destructive and constructive activities are united in the process of rumination. One cannot appreciate the best state of a commonwealth (cf. Logan, p. 41, and CW4, p. 47)

\footnotetext{
${ }^{10}$ Hexter, p. 106; Marius, pp. 190-91.
} 
unless one accepts the worst features of a commonwealth. Hoping for the first and expecting but the latter form realism. Consuming, chewing over, digesting and assimilating this realism needs considerable time.

\section{CHRONOLOGICAL CONTEXT}

Because the duration of such a metabolism cannot be fixed properly, it is worth considering what else moved on in More's mind.

According to More's letter of 1517, the anonymous or fictitious critic observed some absurdities (quaedam subabsurda) in Utopia (cf. Logan, pp. 266-267, and CW4, pp. 248-249). In Utopia, however, More himself admits the same:

Haec ubi Raphael recensuit, quamquam haud pauca mihi succurrebant quae in eius populi moribus legibusque perquam absurde videbantur instituta.

(J.ogan, p. 246)

When Raphael had finished his story, I was left thinking that many of the customs and laws of the Utopians he had described were absurdly instituted.

(cf. Logan, p. 247, and CW4, p. 245)

Due to this, the letter can go on this way:

...non video cur sibi tam oculatus et quod Graeci dicunt o debeat quia aut subabsurda quaedam in Utopiensium institutis deprehenderit... quasi alibi nihil usquam gentium sit absurdi...

(Logan, p. 266)

...I do not see why he should think himself so open-eyed, or, as the Cireek say, 'sharp-sighted,' because he has noted some absurdities in the institutions of the Utopians... Are not there any absurdities elsewhere in the world?

(cf. I.ogan, p. 267, and CW4, p. 249)

There is a shift in connection with the absurdities that turns our attention from the island of Utopia to other nations in the world (cf., alibi usquam gentium). This change renders to the peculiar utopian thoughts the general dimensions of this world. It is on the basis of this expedient that we can accept More's reference to himself as a historian 
(cf. Logan, pp. 268-269, and CW4, pp. 250-251). More and more realism appears in connection with this work of art. With this, More brings his thoughts home.

Admitting the above recognised readjustment, one cannot be surprised seeing More the moral philosopher as More the historiographer, that is, there are two (or three?') works going side by side: Utopia and The History of King Richard the Third/Historia Richardi Regis Angliae Eius Nominis Tertii. ${ }^{11}$ Thomas More, the humanist intellectual, engaged himself with questions which were universal and particular, local and general.

While Utopia was written in 1515-1516, History/Historia came into being between 1513 and 1518 (CW2, p. liii, and pp. Ixiii-lxv). If assimilating the realism of Utopia consumed considerable time, the chewing over of History/Historia was more demanding. More ruminated Utopia returning to it and amending it. More rumination was required by the writing of History/Historia as the topic was simultaneously realised in an English and in a Latin version neither of them being the exact translation of the other (CW2, p. lviii). On the one hand, Utopia gives the impression of a consummate work of art, on the other hand, the composite History/Historia remained unfinished, undigested, so to say.

Reading the compound History/Historia, it is no wonder that Thomas More could not ease his stomach concerning catholic and national matters. When introducing Eduardum, Georgium ac Richardum, that is, Fdwarde, George and Rycharde, More puts down the following:

Qui vt erant omnes illustri loco nati, sic animo etiam elato ac sublimi fuere, auidi gerendi principatus, neque superiorum neque parium satis patiens.

Al three as they wer great states of birthe, soo were they greate and statelye of stomacke, gredye and ambicious of authoritie, and impatient of parteners. (CIV2, p. 6, italics mine)

The English version includes a common metaphor in describing the temper and disposition of the figures of history, and in turn, it becomes a telling image of history itself which yet again challenges people in history whether they can consume it or not. More relies on this set of imagery throughout his work. It goes on accordingly.

For were it by the Queene and the Lordes of her bloode whiche highlye maligned the kynges kinred... or were it a prowde appetite of the Duke himself

11 The Complete Works of St. Thomals Mare. Vol. 2. The I listory of King Richard III, ed. Richard S. Sylvester YNew I Iaven: Yale (iniversity l'ress, 1963), hereafter referred to as CIV2. 
entending to be king: at the lest wise heinous Treason was there layde to his charge, and finallye wer hee fautye were hee faultlesse, attainted was hee by parliament, and iudged to the death, and therupon hastely drouned in a Butte of Malmesey, whose death kynge Edwarde (albeit he commaunded it) when he wist it was done, pitiously bewailed and sorowfully repented.

(CW2, p. 7, italics mine)

This passage portrays history as a digestive system. The variants of this pattern are repeated throughout history. Some lines before the above cited movement of history, More recites Edward's story in short.

Edward reuenging his fathers death, depriued king Henrie, and attained the crown.

$$
\text { (CIW2, pp. 6-7) }
$$

Before too long, Richard has also got his share: some wise men thought that

he long time in king Edwardes life, forethought to be king in case that [the] king his brother (whose life hee looked that euil dyete shoulde shorten) should happen to decease (as in dede he did) while his children wer yonge.

(CIV2, p. 8, italics mine)

Ruminating history results in consuming human beings. That is the world without cnd in Richard's History/Historia. As an effect of this metaphoric metabolism, even the physical-geographical parts of the world are transmuted, especially in the debate about the right of sanctuary in the cataclysm of history. The Duke of Buckingham mentions two places:

...e quibus alterum est vrbi propinquum, alterum in ipsis vrbis visceribus collocatum. Ausim profecto confirmare, quisquis asylorum commoda compararit cum incommodis, eum pronunciaturum potius, quam tot incommoda perpetienda sint, multo fore commodius ipsis etiam commodis caruisse.

The tone at the elboive of the Citie, the tother in the veryc bonvelles. I dare well auowe it, waye the good that they dooe, with the hurte that commeth of them, and ye shall fynde it muche better to lacke bothe, then haue bothe. (CIV2, p. 30, italics mine) 
Due to the metonymy of the incorporated body-image, history totally executes the metamorphosis. The external and the internal parts of the body correspond to the city both within and without. There is no place of protection. The protector's mouthpiece announces in a charming spell like an anagram: the bowelles consume whoever can be found at the elbowe, and vice versa. It is a curse urbi et orbi.

$\Lambda$ s the whole world has become a complete digestive system, none of the intimates of Richard are protected either, not even the "lorde Chamberlen,"

Sed Ilastyngum protector iussit ad mortem se componeret, ac si quid cum sacerdote vellet, accersendum quam primum curaret, nam ita diuum, inquit, Paulum propitium habeam, vt non ante cibi quicquam gustaturus sim quam tibi caput amputatum videam. Ergo ille nihil se reluctando profecturum sciens, adducto quem locus ille offerebat sacerdoti confessionem criminum qualemcunque fecit: nam prolixiorem temporis breuitas non admittebat, protectore iam ad prandium composito, \& vt caput illi praecisum esse audiret intento.

whom the protectour bade spede $\&$ shryue hym a pace, for by saynt Poule (quod he) I wil not to dinner til I se thy bed of. It boted him not to aske why but heuely he toke a priest at aduenture, \& made a short shrift, for a longer would not be suffered, the protectour made so much hast to dyner: which he might not go to til this wer done for sauing of his othe.

(CIV2, p. 49, italics and emphasis mine)

This strange meal was composed by Richard in a delicate way. On the morning of the day in question, Richard turns to the Bishop of Ely:

...pater inquit, fraga tibi in hortis audio insignia nasci, non grauatim scio ferculum vnum tot nobilibus in prandium, velut simbolum tuum conferes. Vtinam, inquit ille, maius aliquid tam facile possim quam hoc, libenter faciam: simulque ministrumqui adferret emittit.

...my lord you haue very good stranberies at your gardayne in Holborne, I require you let vs haue a messe of them. (Gladly my lord, quod he, woulde god I had some better thing as redy to your pleasure as that. And therwith in al the hast he sent hys seruant for a messe of stranberies.

(CW2, p. 47, italics mine)

In such a composition the small berry of a red strawberry as an entrée can metonymically anticipate the main course of bloody beheading. 
In between these two extremes Richard is presented "knitting the browes, frowning and froting and knawing on bys lippes," "obducto supercilio, corrugata fronte admorso labro" (CW2, p. 47, italics mine; cf. Declamatio Thomae Mori Lvcianicae Respondens, where in 1506 the first person singular speaker describes the tyrant after he realises the murder of his son: "Itaque iam nunc uidere mihi uideor micantes latronis oculos obducta supercilia, contractam frontem, genas pallentes, dentes stridentes, labra tumentia." That is: "Even now I seem to see the glittering eyes of the brigand, the knitted brows, the contracted forehead, the pale cheeks, the gnashing teeth, the swelling lips." Then the tyrant commits suicide ${ }^{12}$ ). In his anger and anxiety, the consuming element is fretting and gnawing, that is, consuming a part of his own digestive system. $\Lambda$ t this point metabolism becomes self-destructive katabolism.

It is worth considering that it all happened "on friday" (CW2, p. 46). Friday is a day of fasting traditionally, commemorating the death of the Saviour for the lives of many (cf., Mt 20:28). Richard, however, does not observe this custom (save the strawberries), but violates it, consuming flesh, that is, having Hastings executed for his own sake. In this way he does not reflect the Prototype of kings but becomes an Antitype.

Destruction reaches its totality when Richard devises to pursue his purpose and have himself crowned before anybody "should haue space to dispute \& digest the mater \& make parties," that is depriving men of free assimilation, and when Edmond Shaa, the Mayor of London is ordered to "frame the cite to their appetite" (CWW2, p. 58, italics mine), that is having the people of the city assimilated.

The experience of global and local destruction, universal and atomic corruption, individual and social decay is hard to digest. It can only be ruminated but never assimilated.

12 The Complete Works of St. Thomas More. Vol. 3. Trunslutions of Lucian, ed. Craig R. Thompson (New I laven: Yale University Press, 1974) pp. 122-123. 


\section{INTERNAL CONTEXT}

It is the Bishop of Ely, John Morton who ruminates and helps ruminate the matters which are hard to digest. $\Lambda$ s it has been quoted, when he was asked for his strawberries he did not only send for them in haste, but before sending his servant, he replied to Richard: "...woulde god I had some better thing as redy to your pleasure as that" (CW2, p. 47). Morton thinks first, ruminates before digesting and assimilating anything. $\Lambda$ the end of History, his diplomatic words to the Duke of Buckingham would rather reveal some similar attitude:

...for the weale of this realm, wherof his grace hath now the gouernance, \& wherof I am my self one poore member, I was about to wish, that to those good habilities wherof he hath already right many, litle nedyng my prayse: it might yet haue pleased Godde for the better store, to haue geuen him some of suche other excellente vertues mete for the rule of a realm, as our lorde hath planted in the parsone of youre grace.

(CW2, p. 93)

The elusive style of this concluding passage speaks about the difficulty of digestion. The initial approving praise is followed by some expectancy much to be desired. The praise expected from a man has been eluded, and the expectancy has been also passed, not only up to God, however, but also on to the addressed human person. Though it is not assimilation, yet it is rumination owing to this dual rhetoric.

Rumination in connection with John Morton, who became Archbishop of Canterbury and then also Lord Chancellor of England, re-appears in the chronological context of History/Historia, in Ulopia. For political and private, social and individual reasons More turns to Morton again, and takes his fictitious figures to Morton's table ("in eius mensa," Logan, pp. 54-81, CIV4, pp. 60-85) and the readers are informed of the discussion that took place there. The dialogue embedded within the dialogue of counsel serves as a demonstration and provides a practical approach to answering the question why one should not enter some king's service (Logan, pp. 51-55, CW4, pp. 54-59). More's figures are invited to discuss and digest the given question and the possible answer in the manner of the Utopians' custom of talking during meals (Logan, pp. 142-143, CW4, pp. 144-145). It was Peter Giles who recommended Raphael Hythlodaeus that he should assist a king with counsel. Raphael denounces it in giving his account of the table-talk.

Raphael points out in his conclusion that he wants his audience to see 
the attitude of those who had rejected what I had said first yet who, immediately afterward, when the Cardinal did not disapprove of it, also gave their approval. In fact they went so far in their flattery that they indulged and almost took seriously ideas that their master tolerated only as the clowning of a parasite. From this episode you can see how little courtiers would value me or my advice.

(Logan, pp. 80-81, CIW4, pp. 84-85)

This end reveals that Raphael cannot and will not assimilate the role of a councillor in spite of ruminating its possibility.

Chewing the cud in this demonstrative talk, he speaks about the sheep which are themselves ruminants (Jogan, pp. 62-67, CW4, pp. 65-71). It is a historical problem of society and economy in England. In the late fifteenth and early sixteenth century the increase of sheep farming resulted from the rapid growth of wool industry. It brought about enclosure that meant large grazing lands and required little manpower. It all led to the destruction of many villages (Logan, p. 63, CW4, p. 326). With such background information More has Raphael describing the sheep:

Oves... tam edaces atque indomitae esse coeperunt ut homines devorent ipsos: agros, domos, oppida vastent ac depopulentur.

(Logan, p. 62, italics mine)

...they have become so greedy and fierce that they devour human beings themselves. They devastate and depopulate fields, houses and towns.

(Logan, p. 63, CW4, p. 67, italics mine)

This actually consuming image of the demonstrative part of Book I of Utopia assumes mythological dimensions. This visionary description recalls

Scyllas et Celaenos rapaces et Laestrygonas populivoros

Scyllas and ravenous Celaenos and folk-devouring I aestrygonians

of the previous part of Book I dealing with Raphael's experiences, and proves that "similar frightful monsters are common enough." The archetypal scope is ultimately emphasiscd by More's populivorus, folk-devouring ncologism (I ogan, pp. 48-49, italics mine). 
The mythic power of these sheep are so effective, that they can turn any of the landlords, that is, "the nobility and gentry and some godly abbots - holy men" ("nobiles et generosi atque adeo abbates aliquot, sancti viri"), into "an insatiable glutton and accursed plague of his native land" "'unus helluo inexplebilis ac dira pestis patriae").

This metabolic metamorphosis of mythic effect can be located in the only building preserved in the country, and it is the church. However, the church does not house people attending sacred rituals any more, but in a prophetic-apocalyptic way the sanctuary is converted into a sheep-fold. It means that there is no room for the blessing of the Lamb of God either to save humankind and to provide the bread of life for them any more. In this sense neither the landlords nor the religious pastors tend or pasture those entrusted to them, but they go about their own business (Logan, pp. 6263, CW4, pp. 66-67).

Following the table-talk, the misconduct of these roles is also echoed in the third, theoretical part of Book I:

...magis ad principem eam pertinere curam ut populo bene sit suo quam ut sibi, non aliter ac pastoris officium est oves potius quam semet pascere, quatenus opilo cst.

(Logan, pp. 90-92)

...it is the king's duty to take more care of his people's vvelfare than of his own, just as it is tixe ciut: of a shepherd who cares about his job to feed the sheep rather than himself.

$$
\text { (Logan, pp. 91-93, CIV4, pp. 94-95) }
$$

According to the tablc-talk, the consequences are devastating: destruction of settlements, degradation of people, economic malfunction, cultural and social deviance.

Finishing his discourse on the sheep, Raphael points out some ways to a solution: reconstructing sertements, restoring agriculture, and moderating the wool industry, for cxample. His socio-economic proposals were rejected by the lawyer present at the table. In this rumination, Raphacl could not digest the unbearable socioeconomic problem one had to face in Fngland, and he could not make his proposals either understood or assimilated. On the one hand, his proposals were rebuffed by the lawyer, on the other hand, Cardinal Morton made reservations in the form of questions. 
This reservation almost alludes to the failure of rumination as digestion is dubious and assimilation is questionable. Rehearsing the table-talk, Raphael's attitude and ironic remark as a conclusion can finally sound reasonable:

...ut hinc possis aestimare quanti me ac mea consilia aulici forent aestimaturi.

(Logan, p. 80)

From this you can estimate how little the courtiers would estimate me or my advice.

(Logan, p. 81, CW4, pp. 84-85)

The estimation of this remark alludes to nil.

\section{ALLUSI E CONTEXT}

In More's composition, what Hythlodaeus denounced also affected Morus, and Raphael's reaction must have influenced his ruminative conclusion, too, at the end of Utopia when Morus, "being left thinking" on whatever was related by Raphael ("pauca mihi succurrebant"), "took him by the hand and led him in to supper" ("manu apprehendens intro cenatum duco"):

...facile confiteor permulta esse in Utopiensium republica quae in nostris civitatibus optarim verius quam sperarim.

$$
\text { (I.ogan, pp. 246-248, italics mine) }
$$

...I readily admit that in the Utopian commonwealth there are very many features that in our society I would rather wish than expect to see.

(Logan, pp. 246-249, CW4, pp. 244-247)

The effect of Raphael on Morus can be emphasised by the latter's use of the former's vocabulary in a previous paragraph in a similar context:

...hanc republicae formam, quam omnibus libenter optarim, Utopiensibus saltem contigisse gaudeo...

(Logan, p. 246, italics mine) 
...I am glad that the Utopians at least have been lucky enough to achieve this republic which I wish for all mankind...

(cf. Logan, p. 247, CW4, p. 245)

However, Morus' concluding remark does not only echo Raphael, but he also repeats himself.

In the theoretical third part of Book I, ruminating on the role of a more practical version of philosophy than academic that could be employed "in the council of kings" (Logan, pp. 94-97, CW4, pp. 98-101), Morus outlines the possible tactics relying on an extended stage-metaphor. More, writing this part back in England, makes it more precise with an authentic though common sea-and-ship metaphor:

...est alia philosophia civilior quae suam novit scaenam, eique sese accomodans, in ea fabula quae in manibus est suas partes concinne et cum decore tutatur. Ilac utendum est tibi... Corruperis... perverterisque praesentem fabulam dum diversa permisces, etiamsi ea quae tu adfers meliora fuerint. Quaecumque fabula in manu est, eam age quam potes optime, neque ideo totam perturbes quod tibi in mentem venit alterius quae sit lepidor.

Sic est in republica, sic in consultationibus principum. Si radicitus evelli non possint opiniones pravae nec receptis usu vitiis mederi queas ex animi tui sententia, non ideo tamen deserenda respublica est, et in tempestate navis destituenda est, quoniam ventos inhibere non possis. At neque insuetus et insolens sermo inculcandus quem scias apud diversa persuasos pondus non habiturum, sed obliquo ductu conandum est atque adnitendum tibi uti pro tua virili omnia tractes commode, et quod in bonum nequis vertere efficias saltem ut sit quam minime malum. Nam ut omnia bene sint fieri non potest, nisi omnes boni sint, quod ad aliquot adhinc annos adhuc non exspecto.

(Logan, pp. 94-96, italics mine)

...there is another philosophy, more practical for statesmen, which knows its stage, adapts itself to the play in hand, and acts its part neatly and appropriately. This is the philosophy for you to use... You pervert a play and ruin it when you add irrelevant speeches, even if they are better than the play itself. Whatever play is in hand, act it as best you can, and do not spoil it just because you think of another which has more interest.

So it is in the commonwealth, so it is in the councils of monarchs. If you cannot pluck up bad ideas by the root, or cure long-standing evils to your heart's desire, you must not therefore desert the commonwealth, as you must 
not give up the ship because you cannot control the winds. You must not deliver strange and out-of-the-way speeches to people of opposite conviction with whom they will carry no weight. Instead, by an indirect approach, you must seek and strive as best you can to handle everything tactfully - and what you cannot turn to good, you may at least make as little bad as possible. For it is impossible to make everything good unless all men are good, which I do not expect to see for quite a few years yet.

$$
\text { (cf. Jogan, p. 97, CW4, pp. 99-101) }
$$

Although all these could be taken as a rehearsal of the later More in royal service, yet on the part of Morus, this last sentence in Book I anticipates the end of the rehearsed discourse in Book II, keeping the idea of wishing and the reality of expectancy apart. With this, rumination goes on without proper assimilation except for the assimilation of the two parts of Ltopia by More.

Between these assimilating matters there is another telling comment by Morus. It precedes the closure of the composite of the two books. $\Lambda$ fter Raphael finished his account of Utopia, and before taking him in to supper, Morus was left thinking on some of the absurd laws and customs of the Utopians, but he does not disclose his reservations, rather reserves them for his own later rumination (Logan, pp. 246-249, (.IY 4, p. 244), and then he adds:

... aliud nobis tempus eisdem de rebus altius cogitandi atque uberius cum eo conferendi fore. Quod utinam aliquando contingeret.

$$
\text { (Logan, p. 248) }
$$

...there would be another time for thinking of these matters more thoroughly and for talking them over in more detail. Would that this would happen some day!

$$
\text { (cf. Jogan, p. 249, CIN, p. 245) }
$$

The imperfect subjunctive in the Iatin implies a iasus irrealis, a case never to be realiseci. The content and attitude of this fragment alludes to the reaction of the Ithenians to St. Paul's discourse before the Council of the Areopagus as it is rehearsed in The Alts of the Apostles (17:22-33). St Paul preaches on the knowledge of (jod, a theme very popular in the propaganda of contemporary Hellenistic Judaism. ${ }^{13}$ Paul's speech was terminated with the exclamation by the Greek audience (Acts 17:32):

\footnotetext{
13 Nexander Jones, ed., The Jerusalem Bible (I.ondon: Darton, Longman and Todd, 1966), p.231n.
} 
Audiemus te de hoc iterum.

We would like to hear you talk about this again.

This sudden interruption really meant that the people present could not swallow St Paul's thoughts. Though it was a fiasco, Paul's failure in Athens was all but complete; from now on he refuses to use the devices of Greek philosophy and follows another course:

As for me, brothers, when I came to you, it was not with any show of oratory or philosophy, but simply to tell you what God had guaranteed. During my stay with you the only knowledge I claimed to have was about Jesus, and only about him as the crucified Christ.

(1 Cor 2:1-2)

The same is the case with More. In spite of the popularity of the genre of the speculum, the mirror of princes (Frasmus, Institutio Principis Christiani [1516], Machiavelli, Il Principe [1513], see also (WW4, pp. clxxi-clxxix), More had other points to consider and articulate, which he was already ruminating in Utopia. However, More must have started it earlier, when he translated The Life of Giovanni Pico della Mircundola as a speculum of Christian humanists, and three of his letters, his interpretation of Psalm 16, his twelve rules of a Christian life, his twelve rules of a perfect lover and his deprecatory hymn to God in 1504 before Utopia; and after Utopia, apart from his letters written in the defence of humanism he turned to religious matters from Responsio ad Lutherum (1523) through A Dialogue Concerning Heresies (1529) and A Dialogue of Comforl against Tribulation (1534) to De Tristitia Christi (1534-35), in which he urges his spiritual companion to meditate and ruminate (meditetur ac ruminet). ${ }^{14}$

Thomas More has realised this rumination in Utopia when in the theoretical third part of Book I he gives the essence of speculum regum:

...magis ad principem eam pertinere curam ut populo bene sit suo quam ut sibi, non aliter ac pastoris officium est potius quam semet pascere, quatenus opilio est.

(Logan, pp. 90-92)

14 The Complete Works of St. Thomas More. Vol. 14. De Tristitia Christi, ed. Clarence I1. Miller (New I Iaven: Yale University Press, 1976) p. 253. 
...it is the king's duty to take more care of his people's welfare than of his own, just as it is the duty of a shepherd who cares about his job to feed the sheep rather than himself.

(Logan, pp. 91-93, CW4, pp. 94-95)

On the one hand, More relies indirectly on the Old Testament, the prophets Jeremiah and Ezekiel (cf. CW4, p. 367n):

Doom for the shepherds who... who have not taken care of [the flock].

$$
\text { (cf. Jer 23:1-2) }
$$

Trouble for the shepherds of Israel who feed themselves! Shepherds ought to feed their flock, yet you have... failed to feed the flock. You have failed to make weak sheep strong, or to care for the sick ones, or bandage the wounded ones... my shepherds have stopped bothering about my flock, since my shepherds feed themselves rather than my flock...

(Li:k 34:2b-8)

On the other hand, More directly alludes to the New Testament, The Gospol according to Saint John in which Jesus tells the parable of the model shepherd (Jn 10:1-18, cf. E\%k 34:11-31):

I am the model shepherd;

I know my own

and mine know me

(1) 10:14)

In biblical language 'knowledge' is not merely a conclusion of an intellectual process, but also the fruit of an 'experience' (cf. Lk 15:5), a personal contact (cf. In 10:3b-4, $14: 20,17: 21-22)$. The model shepherd of this specuium perfectionis regum is noble because he is willing to protect his sheep even in risking his own life for them (cf., Jn 10:11b, $15 \mathrm{c}, 17 \mathrm{~b})$ which is an expression of absolute dedication. ${ }^{15}$

Re-considering Utopia, however, it turns out, that Morc was privately dedicated to this model. The source of this dedication can be recognised right at the start of Urutopia, or to be more precise, after satisfying the requirements of dedication and the

${ }^{15}$ Raymond E. Brown, The Gospel according to Jolmn. Vol. 1. (Jondon: (Geoffrey Chapman, 1971, rpt. 1978) pp. 383-400. 
lines of relating the circumstances of the discourse, and before the beginning of Morus's account of his meeting Hythlodaeus. In such a constellation, the lines of conventional dedication are in a peculiarly tight relationship with the narrator's private dedication. The following revelatory lines illuminate the point in question:

Hunc quum die quadam in templo divae Mariae... rei divinae interfuissem, atque peracto sacro pararem inde in hospitium redire...

(Logan, p. 42, italics mine)

One day I had been at divine service in Notre Dame... mass being over, I was about to return to my lodgings...

(cf. J.ogan, p. 43, CW4, p. 49, italics mine)

Morus's dedication takes its origin from the Mass commemorating the Last Supper when Jesus taught his disciples through a discourse during the meal that anticipated the sacrifice of Christ. He is the "Iord of lords and the King of kings" and also the "Lamb" (Rev 17:14), who as a shepherd "lays down his life" for his sheep (cf., Jn $10: 11 b, 15 c, 17 b, 18 b)$ "that they may have life and have it to the full" (In 10:10d-e). One can participate in it by attending the Mass. Mass consists of two parts: the liturgy of the Word and the Liturgy of the Eucharist. In the first part one can ruminate the Word of God as food for thought, and in the second part one can consume the Bread of Iife as food for the soul. Inyone who comes to this table "will never be hungry" (Jn $6: 35 c)$.

Having been weighed against this service, there is no wonder that the offer of royal service needs to be pondered and ruminated. More in Utopia tries assimilating the king's service but he does (iod's first.

\section{PROPOSED INTERPRETATII E CONTEXT}

Having surveyed some contextual aspects of Utopia, it might be deemed well advisable to consider rumination as the nature of More's way of thinking. Neither the structure nor the contents, not even the relation between the structure and the contents seem to be profitable enough to taste Uitopia adequately. Rumination proposes itself as the expedient method that can take the reader closer to More - and more realism in connection with Utopia. 
Reading Thomas More's works, one can recognise the ruminative character that dominates his works of art from the cell in the Charterhouse through his legal career and political performance to the cell in the Tower.

More's torso, his History/Historia remained undigested in spite of its well known end. His completely composed Utopia also waits for assimilation despite its comforting start. The ambiguity of these closures opens unlimited possibilities for the realisation of rumination both for the reader and for More.

In this sense, Utopia is a "libellus vere aureus," that is "a truly golden handbook" (cf. Logan, pp. 1-2, CW4, the title pages of the text). It is golden, but not only because it is a gold-mine of diverse topics, not only because it tries hard to work out the golden mean that it cannot, and not only because its structure resembles the beginning of the golden ratio (the sequence of the Fibonacci numbers: [1:2]) from the point of view of the length of Book I compared to that of Book II. If it were golden from any of these respects only, it would denounce itself, remembering that according to the Utopians "aurum suapte natura tam inutile" (Logan, p. 154) "gold is so useless by its very nature" (cf. Logan, p. 155, CW4, p. 157). However, it is a really golden book, because it does not provide answers ready made for decisive questions, but because it offers a profitable value, an expedient method for reading, writing, and thinking, that is rumination, that can be adapted and employed by anybody.

Thus fulfilling the requirements of the humanist virtues of honestas and utilitas, the reader is neither allowed to face pessimism nor encouraged to entertain optimism, but he is invited to nourish realism. More and more. 